\title{
Phenotypic and genetic characterization of Dunaliella (Chlorophyta) from Indian salinas and their diversity
}

Krishna Preetha, Lijo John, Cherampillil Sukumaran Subin and Koyadan Kizhakkedath Vijayan*

\begin{abstract}
Background: The genus Dunaliella (Class - Chlorophyceae) is widely studied for its tolerance to extreme habitat conditions, physiological aspects and many biotechnological applications, such as a source of carotenoids and many other bioactive compounds. Biochemical and molecular characterization is very much essential to fully explore the properties and possibilities of the new isolates of Dunaliella. In India, hyper saline lakes and salt pans were reported to bloom with Dunaliella spp. However, except for the economically important D. salina, other species are rarely characterized taxonomically from India. Present study was conducted to describe Dunaliella strains from Indian salinas using a combined morphological, physiological and molecular approach with an aim to have a better understanding on the taxonomy and diversity of this genus from India.

Results: Comparative phenotypic and genetic studies revealed high level of diversity within the Indian Dunaliella isolates. Species level identification using morphological characteristics clearly delineated two strains of $D$. salina with considerable $\beta$-carotene content ( $>20 \mathrm{pg} / \mathrm{cell}$ ). The variation in $18 \mathrm{~S}$ rRNA gene size, amplified with MA1-MA2 primers, ranged between $\sim 1800$ and $\sim 2650$ base pairs, and together with the phylogeny based on ITS gene sequence provided a pattern, forming five different groups within Indian Dunaliella isolates. Superficial congruency was observed between ITS and rbcL gene phylogenetic trees with consistent formation of major clades separating Indian isolates into two distinct clusters, one with D. salina and allied strains, and another one with D. viridis and allied strains. Further in both the trees, few isolates showed high level of genetic divergence than reported previously for Dunaliella spp. This indicates the scope of more numbers of clearly defined/unidentified species/subspecies within Indian Dunaliella isolates.

Conclusion: Present work illustrates Indian Dunaliella strains phenotypically and genetically, and confirms the presence of not less than five different species (or sub-species) in Indian saline waters, including D. salina and D. viridis. The study emphasizes the need for a combined morphological, physiological and molecular approach in the taxonomic studies of Dunaliella.
\end{abstract}

Keywords: Dunaliella, Diversity, India, $18 \mathrm{~S}$ rDNA, ITS, rbcL gene

\section{Background}

Dunaliella, the unicellular microalga, is one of the best studied organisms in both general and applied phycology for its higher tolerance to extreme conditions of salinity, light, temperature and $\mathrm{pH}$, as well as for its richness in natural carotenoids, glycerol, lipids and many other bioactive compounds [1-4]. Dunaliella salina is reported as

\footnotetext{
* Correspondence: vijayankk@gmail.com

Genetics and Genomics Section, Marine Biotechnology Division, Central Marine Fisheries Research Institute, Post Box No. 1603, Ernakulam North P.O, Kochi 682018, India
}

the most halotolerant photosynthetic eukaryote with a remarkable degree of tolerance from 0.5 to $5 \mathrm{M}$ salt concentrations (30-300 ppt) [2]. This genus naturally inhabits saline and hypersaline waters and has a cosmopolitan distribution [5] and of the 28 species of Dunaliella, 23 are saline or hypersaline [3,6-9].

Many countries, including India, use $D$. salina for the industrial production of $\beta$-carotene with wide range of applications [4,10-12]. Apart from D. salina, D. tertiolecta is used in aquaculture, while many other species were found promising for the production of biofuel,

\section{Biomed Central}


bioprospecting of antioxidants, bioactive compounds etc. $[4,6]$. Considering the economic importance, most of the studies were mainly focused on the taxonomic, physiological and biotechnological aspects of the halophilic species $D$. salina [5,13-19] (especially from Indian subcontinent) and on the marine species $D$. tertiolecta. But similar exclusive or comparative studies are rarely available for other species [20-23], probably due to their lesser importance and/or limited distribution.

Typically the taxonomy of Dunaliella anchors on the morphological and physiological features of the organism. Apart from the general morphology, salinity tolerance and carotenoid (especially $\beta$-carotene) production are the two commonly studied physiological attributes of Dunaliella, where considerable variations have been accounted at inter and intra-species levels [24,25]. Recently, Borowitzka and Siva [3] have given a detailed account of taxonomic revision of the genus Dunaliella with special emphasis on saline species bringing more clarity in classification. Dunaliella are unique in having a thin plasma membrane instead of a rigid cell wall [26] and are able to change their cell shape and volume in response to changes in osmolarity and other growth conditions [17,27-29]. Due to this high plasticity of cell morphology, the traditional practice of species differentiation merely based on light microscopic observations becomes difficult and time consuming. Consequently many misidentifications arose in the literature which brought in controversies and confusions in the taxonomic organization of the genus Dunaliella [3,5].

Molecular taxonomy emerged as a faster and powerful tool as it is consistent and independent from environmental factors and growth stages [30]. It seems to be an advanced and reliable device for the characterization and differentiation of morphologically plastic organisms. Since 1999, molecular characterization has been found promising in the taxonomy of Dunaliella [6,29]. Currently $18 \mathrm{~S}$ rRNA gene [5,31], Internal Transcribed Spacer (ITS) region [14,23,27] and large subunit of the ribulose-bisphosphate carboxylase $(r b c \mathrm{~L})$ gene [9] are being widely used as effective molecular tools in Dunaliella characterization and biodiversity studies. Use of these molecular markers has resulted in the redesignation of many species [8,32]. Nevertheless, the confusion regarding the taxonomy still persists due to the misidentifications, and will be there until a complete revision is made, using an integrated approach with molecular phylogeny, supported by morphological and physiological attributes. Many researchers opined to have such an integrated approach rather than a single system of taxonomic identification [3,32].

In India, Dunaliella are found in salt pans, saline and hypersaline ponds, lakes, pools etc. as a major primary producer. Many species including D. salina have been reported [33] to form blooms in salt pans. However, taxonomic characterization of Indian Dunaliella strains based on phenotypic and molecular traits is rarely available. In this background, we conducted a study on the characterization of Dunaliella strains isolated from the Indian salinas, using morphological, physiological and molecular tools and have made an attempt to depict the best possible description on Indian Dunaliella spp. Based on the results obtained, taxonomic position and diversity aspects of the Genus Dunaliella from Indian salinas are discussed.

\section{Results and discussion}

\section{Morphological \& physiological parameters}

Morphologically all ten strains of the green biflagellate chlorophytes, isolated from 7 different locations along the Indian coast (Figure 1 \& Table 1), were identified as Dunaliella (Figure 2) following the revision of the genus by Borowitzka and Siva [3]. Of the 10 strains, 9 were isolated from hypersaline water bodies and 1 (S135) was marine. Though purified by agar plating, the cultures were not axenic. All morphological characteristics of different geographical Indian isolates of Dunaliella are summarized in Table 2.

High levels of morphological plasticity in cell shape and size was observed among all the 10 Dunaliella, strains, but a general consistency in cell size was noticed within the range given (Table 3) [34,35]. Among the 10 strains, S135 (Calicut, marine isolate), S089 (CMFRI old strain isolated from Chennai) and S147 (Kutch) were considerably larger while strain S133 (Kutch) was the smallest.

In salinity tolerance study $(0.5-4.5 \mathrm{M} \mathrm{NaCl})$, sufficient growth (approximately 5-20 million cells $/ \mathrm{ml}$ in 28 days from an initial cell density of $15-60$ thousand cells $/ \mathrm{ml}$ ) was obtained for each strain in different salinities with optimum growth at 1.5 or $2.5 \mathrm{M}$ salt concentrations (growth rate was $0.1 \pm 0.05$ div.d $^{-1}$ during exponential growth period), emphasizing that all the strains (including the marine isolate S135) are halophilic in nature. Beta carotene was quantified in all the isolates (Table 2) at 'normal' and stressed growth conditions. Under stress (3.5M NaCl, irradiance of 100-150 $\mu \mathrm{mol}$ photons $\mathrm{m}^{-2} \mathrm{~s}^{-1}$ ) higher level of the pigment (23.4 \& $22.9 \mathrm{pg} / \mathrm{cell})$ was recorded in the 2 Indian strains, S089 and S135 respectively while for the Australian reference strain $D$. salina CS265, it was nearly $36 \mathrm{pg} / \mathrm{cell}$. The 3 strains turned orange/red at high salinity (Figure $2, \mathrm{c}, \mathrm{m} \& \mathrm{p}$ ). Lower quantities of the pigment $(<2 \mathrm{pg} /$ cell $)$ were observed in the strain S133 from Kutch and the 2 Goa strains, S122 and S125. For the remaining strains it was around 2-7 pg/cell, under stress.

Among the many listed attributes, cell size, colour, stigma and $\beta$-carotene accumulation are the major traits used to discriminate carotenogenic Dunaliella spp. like 


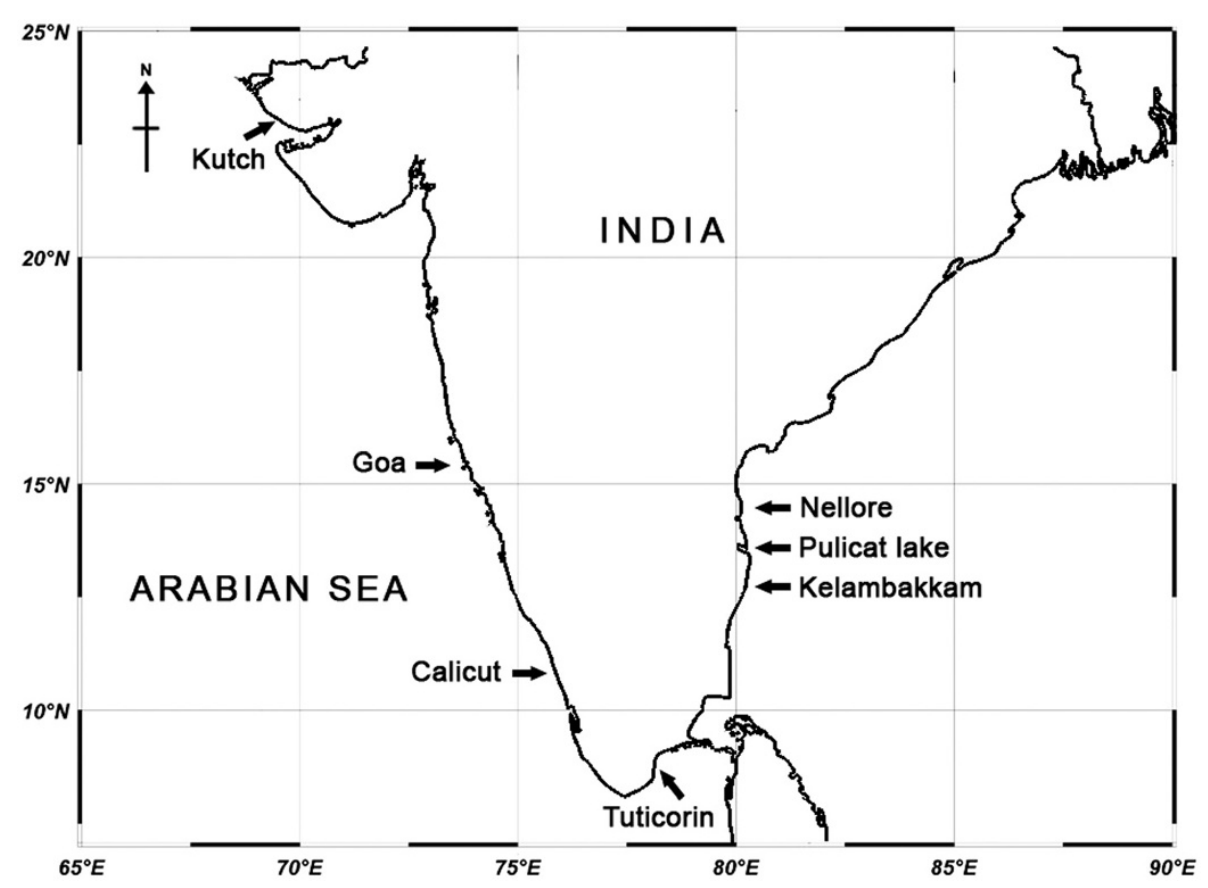

Figure 1 Sampling locations of Dunaliella strains used in the present study along the Indian coast.

D. salina and D. bardawil/salina. Red D. salina (especially at high salinity) was reported to have significantly large cell size than other common strains like D. parva, $D$. viridis and D. tertiolecta [3]. Limited carotenogenic capacity also discriminated other strains from $D$. salina where the latter can accumulate $>20 \mathrm{pg} \beta$-carotene/cell [3]. Coesel et al. [36] and Olmos et al. [5] obtained 10 $\mathrm{pg} /$ cell of $\beta$-carotene under non-stressful growth conditions for the two hyper producing strains of $D$. salina, CCAP $19 / 30$ and $19 / 18$ respectively. In the present study, morphological and physiological observations of the 2 strains, S089 and S135, revealed that they are Indian strains of $D$. salina. Discrimination derived from basic morphology (taxonomic key), characterized the remaining strains as $D$. viridis except $\mathrm{S} 125$ (D. minuta?), S133 (D. viridis/D. bioculata?) and S147 (Dunaliella sp.) (Table 2). Detailed morphology and physiology based studies illustrated considerable diversity within the Indian strains of Dunaliella but a little confusion prevailed due to overlapping features with more than one reported species (like the cell size increase and $\beta$-carotene content of strains S121 and S118 at higher salinity, two stigmata of S133 at lower salinity and pyrenoid characteristics of S125) (Tables 2 and 3). In the present investigation, molecular characterization was used as a tool to resolve the confusion.

Molecular characterization based on 18S rRNA gene size Amplification of $18 \mathrm{~S}$ rRNA gene with primers MA1 \& MA2 from different Dunaliella isolates in the present study gave products with size ranging from $\sim 1820-2640 \mathrm{bp}$ (Table 1 \& Figure 3 ). The banding pattern observed among the present isolates was found matching with the reported gene sizes of $18 \mathrm{~S}$ rDNA using MA1-MA2 primers $[5,29]$. The dissimilarity in product size observed among the different isolates could be explained based on the presence/absence or difference in the size of introns across different species of Dunaliella [5,29]. With regard to the presence of 3 types of Group I introns in $18 \mathrm{~S}$ rRNA gene [37], Olmos et al., [31,38] designed a set of conserved primers (MA1, MA2 \& MA3) and a set of species specific primers (DSs, DPs, DBs). They used the conserved primers (MA1 \& MA2) for preliminary differentiation of various known species of Dunaliella based on the size of the PCR product. Subsequently, morphologically identical Dunaliella strains (e.g., D. salina and D. bardawil) got discriminated by position and number of the introns $[5,29]$. Based on these reports $18 \mathrm{~S}$ rDNA of D. tertiolecta ( $1770 \mathrm{bp})$ lacks an intron, D. salina ( $2170 \mathrm{bp}$ ) has only one intron at 5 ' terminus, $D$. viridis ( 2495 bp) has one longer intron again at 5' terminus and D. parva and D. bardawil have two introns ( $2570 \mathrm{bp})$ one each at 5' and 3' terminus. Other than these strains, $D$. peircei having $\sim 2088 \mathrm{bp}$ (one intron at $5^{\prime}$ terminus) was also reported.

In the present study, based on the $18 \mathrm{~S}$ rDNA gene size, clear grouping of all the 10 Indian Dunaliella strains was possible (Figure 3 \& Table 1). Out of the 10 strains only 1 strain, S147 (Kutch) produced the shortest band ( 1820 bp) showing similarity to that reported for 
Table 1 Geographical origin and gene sequence accession details of Dunaliella strains studied in the present work

\begin{tabular}{|c|c|c|c|c|c|c|c|c|c|}
\hline \multirow[t]{2}{*}{ Groups } & \multirow[t]{2}{*}{$\begin{array}{l}\text { Strain } \\
\text { code }\end{array}$} & \multirow[t]{2}{*}{$\begin{array}{l}\text { Isolated } \\
\text { from }\end{array}$} & \multirow[t]{2}{*}{$\begin{array}{l}\text { Geographic } \\
\text { co-ordinates }\end{array}$} & \multirow[t]{2}{*}{$\begin{array}{l}\text { Month of } \\
\text { collection }\end{array}$} & \multirow[t]{2}{*}{$\begin{array}{l}\text { Salinity of the } \\
\text { sampled water }\end{array}$} & \multirow[t]{2}{*}{$\begin{array}{l}18 \mathrm{~S} \text { rDNA } \\
\text { product size }\end{array}$} & \multicolumn{3}{|c|}{$\begin{array}{c}\text { Genebank } \\
\text { accession No. }\end{array}$} \\
\hline & & & & & & & $18 \mathrm{~S}$ rDNA & ITS region & $r b c L$ gene \\
\hline & CS265 & Dunaliella salina; Refere & strain from CSIRO & ion of living mic & e, Australia & $2210 \mathrm{bp}$ & JN807321 & JN797804 & JN797820 \\
\hline \multirow[t]{2}{*}{ । } & MBTD-CMFRI-S135 & Sea water, Calicut, Kerala (WC) & $11^{\circ} 15^{\prime} N 75^{\circ} 46^{\prime} \mathrm{E}$ & May 2009 & $33 \mathrm{ppt}$ & $2230 \mathrm{bp}$ & JF708161 & JN797802 & JN797818 \\
\hline & MBTD-CMFRI-S089 & $\begin{array}{l}\text { Kelambakkom salt pan, } \\
\text { Chennai, TN (EC) }\end{array}$ & \multicolumn{3}{|c|}{$\begin{array}{l}\text { Culture maintained in CMFRI phytoplankton culture collection, } \\
\text { isolated from Chennai salt pan. }\end{array}$} & $2210 \mathrm{bp}$ & JF708173 & JN797806 & JN797811 \\
\hline \multirow[t]{3}{*}{$\|$} & MBTD-CMFRI-S118 & Salt pan, Nellore, AP (EC) & $14^{\circ} 16^{\prime} \mathrm{N} 80^{\circ} 07^{\prime} \mathrm{E}$ & March 2009 & $300 \mathrm{ppt}$ & $2290 \mathrm{bp}$ & JN807316 & JN797808 & JN797813 \\
\hline & MBTD-CMFRI-S086 & Salt pan, Tuticorin, TN, (EC) & $08^{\circ} 47^{\prime} N 78^{\circ} 09^{\prime} \mathrm{E}$ & February 2009 & $300 \mathrm{ppt}$ & $2290 \mathrm{bp}$ & JF708169 & JN797805 & JN797810 \\
\hline & MBTD-CMFRI-S121 & Pulicat salt lake, AP (EC) & $13^{\circ} 40^{\prime} \mathrm{N} 80^{\circ} 11^{\prime} \mathrm{E}$ & March 2009 & $150 \mathrm{ppt}$ & $2250 \mathrm{bp}$ & JN807317 & JN797809 & JN797814 \\
\hline \multirow[t]{3}{*}{ III } & MBTD-CMFRI-S115 & $\begin{array}{l}\text { Kelambakkom salt pan, } \\
\text { Chennai, TN (EC) }\end{array}$ & $12^{\circ} 45^{\prime} \mathrm{N} 80^{\circ} 12^{\prime} \mathrm{E}$ & March 2009 & $380 \mathrm{ppt}$ & $2550 \mathrm{bp}$ & JN807315 & JN797807 & JN797812 \\
\hline & MBTD-CMFRI-S122 & Salt pan, Ribandar, Goa (WC) & $15^{\circ} 30^{\prime} \mathrm{N} 73^{\circ} 51^{\prime} \mathrm{E}$ & May 2009 & $280 \mathrm{ppt}$ & $2550 \mathrm{bp}$ & JN807318 & JN797799 & JN797815 \\
\hline & MBTD-CMFRI-S133 & Salt pan, Kutch, Gujarat (WC) & $23^{\circ} 50^{\prime} \mathrm{N} 69^{\circ} 39^{\prime} \mathrm{E}$ & July 2009 & $320 \mathrm{ppt}$ & $2530 \mathrm{bp}$ & JF708183 & JN797801 & JN797817 \\
\hline IV & MBTD-CMFRI-S125 & Salt pan, Pilar, Goa (WC) & $15^{\circ} 26^{\prime} N 73^{\circ} 53^{\prime} \mathrm{E}$ & May 2009 & $260 \mathrm{ppt}$ & $2640 \mathrm{bp}$ & JN807319 & JN797800 & JN797816 \\
\hline V & MBTD-CMFRI-S147 & Salt pan, Kutch, Gujarat (WC) & $23^{\circ} 50^{\prime} \mathrm{N} 69^{\circ} 39^{\prime} \mathrm{E}$ & April 2009 & $180 \mathrm{ppt}$ & $1820 \mathrm{bp}$ & JN807320 & JN797803 & JN797819 \\
\hline
\end{tabular}

NB: For convenience strain codes used in text included only third part of full strain code (e.g., S086). AP, Andhra Pradesh; TN, Tamil Nadu; WC-west coast; EC, east coast.

Indian strains were grouped into subsets based on the $18 \mathrm{~S}$ rDNA size obtained by PCR amplification with MA1-MA2 primers. 


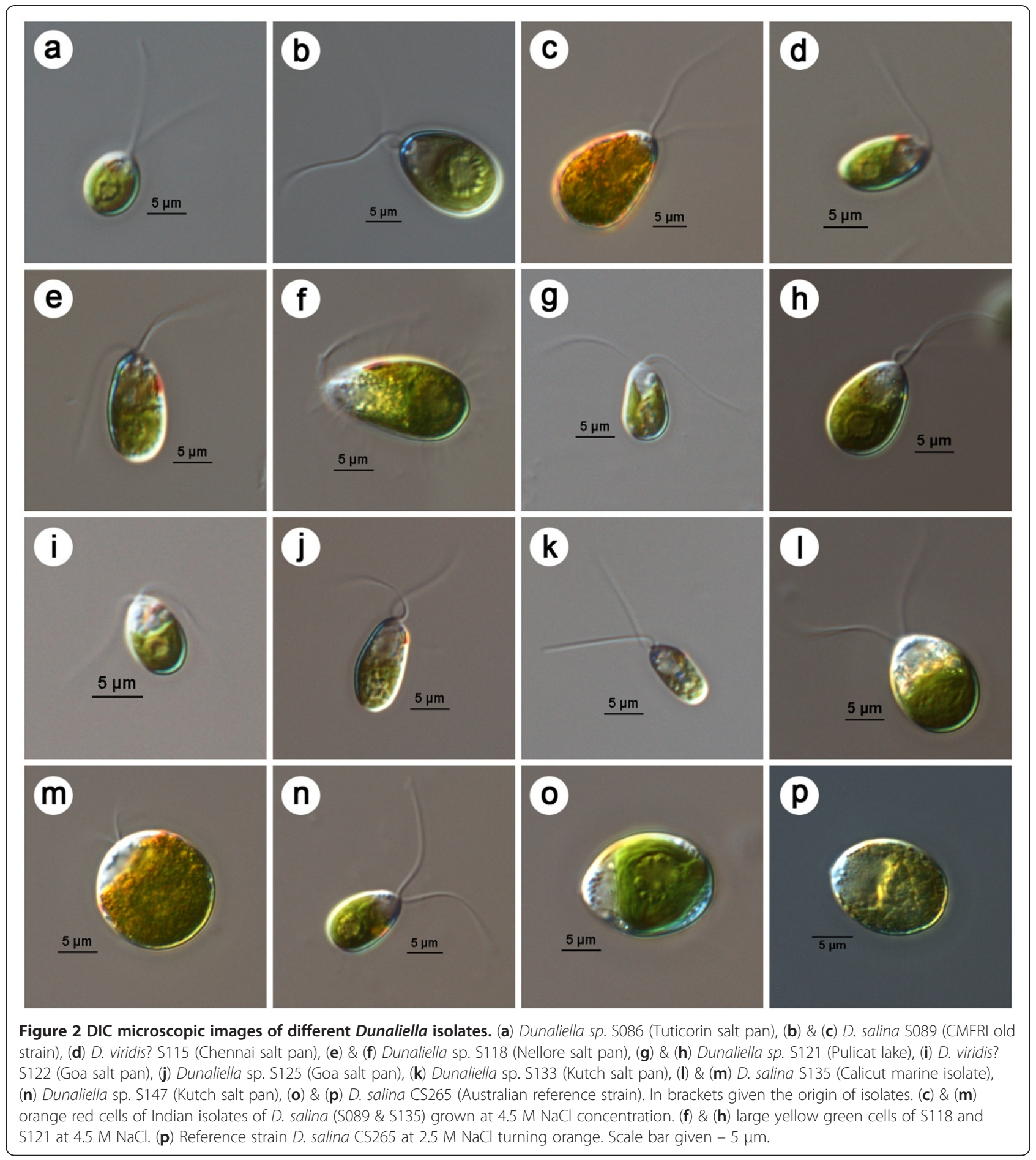

D. tertiolecta ( 1770 bp) probably due to the absence of any introns (Group V). The 2 Indian strains S089 (CMFRI old strain, Chennai) and S135 (Calicut marine isolate) and the reference strain CS265 (D. salina) produced $\sim 2200$ bp size band (Table 1) closer to the reported D. salina ( 2170 bp). This further supported phenotypic identification of the above 2 Indian strains as
D. salina (Group I). Studies using the $18 \mathrm{~S}$ PCR products revealed a clear separation of morphologically similar strains (D. viridis?), into 2 groups - (Group II \& Group III in Table 1 \& Figure 3). The $18 \mathrm{~S}$ rDNA size ( 2300 bp) of Group II strains (S086 (Tuticorin), S118 (Nellore) \& S121 (Pulicat)) was showing an indication that these strains are more close to $D$. salina than $D$. viridis. While 
Table 2 Morphological and physiological characteristics of 10 Indian Dunaliella strains

\begin{tabular}{|c|c|c|c|c|c|c|c|c|c|c|c|}
\hline Groups & $\begin{array}{l}\text { Strain } \\
\text { Code }\end{array}$ & $\begin{array}{l}\text { Cell } \\
\text { colour }\end{array}$ & $\begin{array}{l}\text { Cell } \\
\text { shape }\end{array}$ & $\begin{array}{l}\text { Flagella } \\
\text { length }\end{array}$ & Stigma & Pyrenoid & $\begin{array}{l}\text { Refractile } \\
\text { granules }\end{array}$ & $\begin{array}{l}\text { Mode of } \\
\text { reproduction } \\
\text { observed }\end{array}$ & $\begin{array}{c}\beta \text { Carotene } \\
\text { normal/stress } \\
(\mathrm{pg} / \mathrm{cell})\end{array}$ & $\begin{array}{l}\text { Salinity } \\
\text { optimum }\end{array}$ & Identified as \\
\hline \multirow[t]{2}{*}{ I } & MBTD-CMFRI-S135 & Green to red & $\begin{array}{l}\text { Ovoid, spherical, } \\
\text { cylindrical }\end{array}$ & $\begin{array}{l}1.3 \text { or } 1.5 \text { to } \\
\text { cell length }\end{array}$ & $\begin{array}{l}\text { Not clearly visible } \\
\text { or diffuse }\end{array}$ & $\begin{array}{l}\text { Large with } \\
\text { distinct } \\
\text { amylosphere }\end{array}$ & Absent & Cell division & $8.68 / 22.94$ & $1.5 \mathrm{M} \mathrm{NaCl}$ & D. salina \\
\hline & MBTD-CMFRI-S089 & Green to red & Ovoid, spherical & 1.3 to cell length & $\begin{array}{l}\text { Not visible/ } \\
\text { Diffuse large }\end{array}$ & $\begin{array}{l}\text { Large with } \\
\text { distinct } \\
\text { amylosphere }\end{array}$ & Absent & Cell division & $6.53 / 23.36$ & $1.5 \mathrm{M} \mathrm{NaCl}$ & D. salina \\
\hline \multirow[t]{3}{*}{$\|$} & MBTD-CMFRI-S118 & $\begin{array}{l}\text { Green to } \\
\text { orange }\end{array}$ & Ovoid spherical & 1.5 to cell length & $\begin{array}{l}\text { One; large, red, } \\
\text { median, diffuse }\end{array}$ & $\begin{array}{l}\text { Small with } \\
\text { amylosphere }\end{array}$ & Absent & $\begin{array}{l}\text { Sexual, } \\
\text { cell division }\end{array}$ & $2.11 / 3.47$ & $2.5 \mathrm{M} \mathrm{NaCl}$ & Dunaliella sp. \\
\hline & MBTD-CMFRI-S121 & Green & Ovoid pyriform & 1.5-2 to cell length & $\begin{array}{l}\text { One; large, red, } \\
\text { median, distinct }\end{array}$ & $\begin{array}{l}\text { Large with } \\
\text { amylosphere }\end{array}$ & Absent & $\begin{array}{c}\text { Sexual, } \\
\text { cell division }\end{array}$ & $1.59 / 2.17$ & $1.5 \mathrm{M} \mathrm{NaCl}$ & Dunaliella sp. \\
\hline & MBTD-CMFRI-S086 & Green & $\begin{array}{l}\text { Ovoid, oval } \\
\text { or pyriform }\end{array}$ & 1.5- 2 to cell length & $\begin{array}{l}\text { One; Small, red, } \\
\text { median, distinct }\end{array}$ & $\begin{array}{l}\text { Small with } \\
\text { amylosphere }\end{array}$ & Present & $\begin{array}{c}\text { Sexual, } \\
\text { cell division }\end{array}$ & $2.68 / 3.41$ & $0.5 \mathrm{M} \mathrm{NaCl}$ & Dunaliella sp. \\
\hline \multirow[t]{3}{*}{ III } & MBTD-CMFRI-S115 & Green & $\begin{array}{l}\text { Ovoid, oval } \\
\text { or fusiform }\end{array}$ & 1.3 to cell length & $\begin{array}{l}\text { One; small, red, } \\
\text { anterior, distinct }\end{array}$ & $\begin{array}{l}\text { Small with } \\
\text { amylosphere }\end{array}$ & Absent & $\begin{array}{l}\text { Palmella, } \\
\text { aplanospores }\end{array}$ & $1.05 / 1.99$ & $1.5 \mathrm{M} \mathrm{NaCl}$ & D. viridis? \\
\hline & MBTD-CMFRI-S122 & Green & Oval, cylindrical, & 1.3 to cell length & $\begin{array}{l}\text { One; large, red, } \\
\text { anterior, distinct, }\end{array}$ & $\begin{array}{l}\text { Large, } \\
\text { Amylosphere }\end{array}$ & Present & Palmella stage & $0.67 / 1.78$ & $1.5 \mathrm{M} \mathrm{NaCl}$ & D. viridis? \\
\hline & MBTD-CMFRI-S133 & $\begin{array}{l}\text { Yellow } \\
\text { green }\end{array}$ & Fusiform, Elliptical & 1.3 to cell length & $\begin{array}{l}\text { One, Two at } \\
\text { lower salinity; } \\
\text { small, red, } \\
\text { median, distinct }\end{array}$ & $\begin{array}{l}\text { Small, with } \\
\text { amylosphere }\end{array}$ & Absent & $\begin{array}{l}\text { Cell division, } \\
\text { Palmella, } \\
\text { aplanospores }\end{array}$ & $0.51 / 1.26$ & $1.5 \mathrm{M} \mathrm{NaCl}$ & $\begin{array}{l}\text { D.viridis/ } \\
\text { D. bioculata? }\end{array}$ \\
\hline IV & MBTD-CMFRI-S125 & Green & Cylindrical fusiform & $\begin{array}{l}\text { Equal or } 1.3 \text { to } \\
\text { cell length }\end{array}$ & $\begin{array}{l}\text { One, large, red, } \\
\text { anterior, distinct }\end{array}$ & $\begin{array}{l}\text { Small, with distinct } \\
\text { separate } \\
\text { starch grains }\end{array}$ & Absent & Cell division & $0.70 / 1.8$ & $1.5 \mathrm{M} \mathrm{NaCl}$ & D. minuta? \\
\hline V & MBTD-CMFRI-S147 & Green & Oval, fusiform & $\begin{array}{l}1.5 \text { or } 2 \text { to } \\
\text { cell length }\end{array}$ & $\begin{array}{l}\text { One, large, red, } \\
\text { median distinct }\end{array}$ & $\begin{array}{l}\text { Large with } \\
\text { amylosphere }\end{array}$ & Present & $\begin{array}{c}\text { Palmella } \\
\text { (dominant stage), } \\
\text { Cell division }\end{array}$ & $0.89 / 6.7$ & $1.5 \mathrm{M} \mathrm{NaCl}$ & Dunaliella sp. \\
\hline
\end{tabular}

Grouping of the subsets was formed based on common morphological features including cell size and $\beta$-carotene accumulation at high salinity and light (stress). 
Table 3 Descriptive statistics of cell size variables and F-values (derived from the analysis of variance) of different Dunaliella isolates from Indian coast

\begin{tabular}{|c|c|c|c|c|c|c|c|c|c|c|c|}
\hline \multirow{2}{*}{$\begin{array}{l}\text { Groups } \\
\text { Strain code }\end{array}$} & \multicolumn{2}{|c|}{1} & \multicolumn{3}{|c|}{ II } & \multicolumn{3}{|c|}{ III } & \multirow{2}{*}{$\frac{\text { IV }}{\text { MBTD-CMFRI-S125 }}$} & \multirow{2}{*}{$\frac{\mathrm{v}}{\text { MBTD-CMFRI-S147 }}$} & \multirow[b]{2}{*}{$\mathrm{F}$ value } \\
\hline & MBTD-CMFRI-S135 & MBTD-CMFRI-S089 & MBTD-CMFRI-S086 & MBTD-CMFRI-S118 & MBTD-CMFRI-S121 & MBTD-CMFRI-S115 & MBTD-CMFRI-S122 & MBTD-CMFRI-S133 & & & \\
\hline Length $\mu \mathrm{m}$ & $\begin{array}{c}17.51 \pm 1.78 \\
(12.30-21.17)\end{array}$ & $\begin{array}{c}14.12 \pm 2.25 \\
(10.01-18.82)\end{array}$ & $\begin{array}{c}9.15 \pm 1.02 \\
(6.44-10.68)\end{array}$ & $\begin{array}{c}9.51 \pm 1.09 \\
(7.96-12.25)\end{array}$ & $\begin{array}{c}9.37 \pm 1.30 \\
(6.45-11.77)\end{array}$ & $\begin{array}{c}9.02 \pm 0.96 \\
(6.79-12.12)\end{array}$ & $\begin{array}{c}8.46 \pm 1.12 \\
(5.62-10.55)\end{array}$ & $\begin{array}{l}7.91 \pm 0.93 \\
(6.54-9.78)\end{array}$ & $\begin{array}{c}9.89 \pm 1.37 \\
(8.38-12.99)\end{array}$ & $\begin{array}{r}11.17 \pm 1.50 \\
(8.02-13.83)\end{array}$ & $138.33^{*}$ \\
\hline Width $\mu \mathrm{m}$ & $\begin{array}{l}10.30 \pm 1.96 \\
(8.61-19.79)\end{array}$ & $\begin{array}{c}9.57 \pm 1.35 \\
(7.46-12.58)\end{array}$ & $\begin{array}{l}6.14 \pm 0.92 \\
(3.52-8.08)\end{array}$ & $\begin{array}{c}6.91 \pm 0.74 \\
(5.84-8.76)\end{array}$ & $\begin{array}{l}5.94 \pm 0.96 \\
(4.14-7.54)\end{array}$ & $\begin{array}{l}5.09 \pm 0.77 \\
(3.02-6.98)\end{array}$ & $\begin{array}{l}4.74 \pm 0.48 \\
(3.91-5.76)\end{array}$ & $\begin{array}{l}3.89 \pm 0.60 \\
(3.11-5.10)\end{array}$ & $\begin{array}{l}4.34 \pm 0.69 \\
(3.27-5.95)\end{array}$ & $\begin{array}{c}7.23 \pm 1.15 \\
(5.40-10.07)\end{array}$ & $125.85^{*}$ \\
\hline
\end{tabular}

Measurements are presented as, Mean \pm SD (min. - max.); *Significant at the $1 \%$ level; SD is standard deviation.

Grouping of subsets was statistically formed based on the average length/width of the Dunaliella cells. 


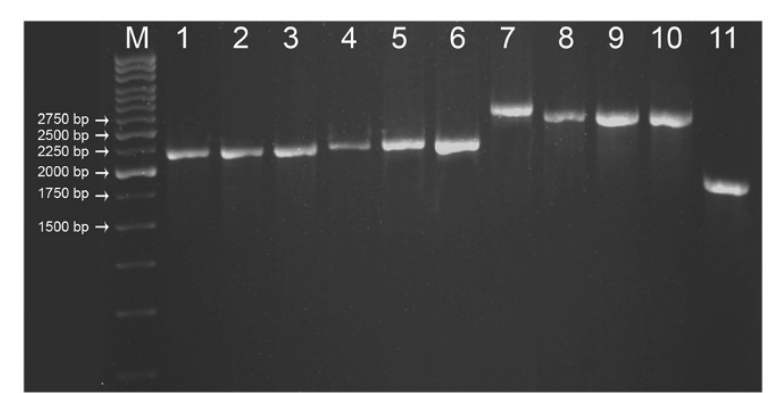

Figure 3 18S rDNA amplification with MA1 \& MA2 primers in 1\% Agarose gel. Lane 1-11 CS265, MBTD-CMFRI-S089, S135, S086, S118, S121, S125, S115, S122, S133 and S147 respectively \& Lane M -250 bp ladder (Genie, India).

group III strains (S122 (Goa), S115 (Chennai) \& S133 (Kutch)) gave a band size of $\sim 2550 / 2530$ bp which could be compared to the reported $D$. viridis (2495 bp) or $D$. parva ( 2570 bp) probably with 1 or 2 introns. The band size of the Goa strain S125 ( 2640 bp, Group IV) was however not in accordance with any of the reported species of Dunaliella [5]. Partial ( 600 bp) sequencing of 5 ' terminus region of the PCR products could not confirm the presence of any introns, while the generated partial sequence information (refer Table 1 for GenBank accessions) was found to be highly conserved across species and therefore could not specify the species delineation. Further characterization was carried out based on molecular phylogeny of a more variable ITS region and a conserved $r b c \mathrm{~L}$ gene for more clarification about species lineages of Indian Dunaliella.

\section{ITS phylogeny}

The phylogenetic analysis based on ITS region ( 700 bp) using maximum likelihood confirmed high level of genetic diversity within Indian Dunaliella isolates. All Dunaliella spp. (including the sequences from NCBI, Table 4) were found to be separated into 3 major clusters, with Chlamydomonas reinhardtii forming an out group as expected (Figure 4). Majority of the named species of Dunaliella from NCBI were found to be grouped under a single cluster (clade 1) except D. salina CCAP 19/18, D. salina/D. viridis CCAP 19/3, D. viridis CONC 002 and Dunaliella spp. ABRIINW M1/2, SPMO 200-2, SPMO 600-1 and the reference strain of $D$. salina CS265. When out grouped with D. tertiolecta (Figure 5), the ITS tree branching was found well supporting the morphology and 18S rRNA gene size based grouping (Group I-V) of the 10 new isolates of Dunaliella.

The genetic divergence values observed among clade 2 (Figure 4) isolates ranged up to 9.1\% (between S089 \& CCAP 19/3), which was comparable to that observed between different species of the genus Dunaliella [14,17]. The 2 Indian D. salina strains (Group I, Figure 5) S089
Table 4 Sequence accession no.s of Dunaliella and other strains from NCBI database included in present study

\begin{tabular}{lcc}
\hline Strain & $\begin{array}{c}\text { ITS Accession } \\
\text { No. }\end{array}$ & $\begin{array}{c}\text { rbcL Accession } \\
\text { No. }\end{array}$ \\
\hline D tertiolecta CCAP 19/27 & EF473748 & \\
D tertiolecta ATCC 30929 & EF473742 & \\
D tertiolecta SAG 13.86 & EF473738 & \\
D tertiolecta Dtsi & EF473730 & \\
D tertiolecta CCMP 1302 & & DQ313205 \\
D tertiolecta UTEX 999 & & DQ313203 \\
D peircei/D viridis UTEX 2192 & & DQ313196 \\
D primolecta & DQ116745 & DQ173090 \\
D primolecta & & AB127992 \\
D primolecta UTEX 1000 & & DQ313198
\end{tabular}

D parva

DQ116746

D parva/D viridis UTEX 1983

AJ001877

D bioculata UTEX 199

DQ377086

DQ313195

D bioculata

$\mathrm{AB} 127991$

$D$ salina Dsge

EF473732

D salina SAG 42.88

EF473741

Dunaliella sp. hd10

DQ116747

D salina Ds18S3

FJ360758

D salina Ds18S1

FJ360756

D salina/D viridis CCAP 19/3 (UTEX 200)

EF473744

DQ313197

D salina CCAP 19/18

EF473746

GQ250046

$D$ viridis CONC 002

DQ377098

DQ313206

Dunaliella sp. ABRIINW M1/2

EU927373

Dunaliella sp. SPMO 200-2

DQ377106

DQ313211

Dunaliella sp. SPMO 600-1

DQ377120

DQ313218

Chlamydomonas reinhardtii

AB511842

Paulschulzia pseudovolvox

D86837

(CMFRI old strain) and S135 (Calicut marine isolate) got clustered with the Australian D. salina strains CS265 and CCAP 19/18 with divergence values ranging from $1.9 \%$ (between CS 265 \& CCAP 19/18) to 5.6\% (between S089 \& S135). Whereas, the strains S086 (Tuticorin), S121 (Pulicat) and S118 (Nellore) were found closer to D. salina/D. viridis CCAP $19 / 3$. The much higher divergence $(>8 \%)$ of the 3 Indian strains from the carotenogenic D. salina strains (CCAP19/18 and CS265) was in agreement with the grouping of the 3 strains in Group II (Figure 5) based on the morphological, physiological and $18 \mathrm{~S}$ rDNA size based analyses.

The remaining 5 Indian Dunaliella strains (S115, S122, S125, S133 and S147) along with D. viridis CONC 002 formed a separate cluster (clade 3 of Figure 4). The strains showed divergence range from 0\% (between S115 \& S122) to $7.6 \%$ (between S147 and D. viridis CONC 
002). The 2 D. viridis(?) strains S115 (Chennai) \& S122 (Goa) and the D. viridis/D. biocuata(?) strain S133 (Kutch) were found in close proximity (mean divergence of 2.22\%) with CONC 002 D. viridis (Group III of Figure 5). The other 2 strains S125 and S147 (Group IV \& V of Figure 5) were found to be well separated from the above group with divergence values of $4.98 \%$ and $6.42 \%$ respectively with $D$. viridis CONC 002.

The mean pair wise genetic distance values observed among the Indian isolates of the 2 major clades $(5.35 \%$ for clade 2 and $5.12 \%$ for clade 3 ) were comparatively higher than that observed among the named species of Dunaliella (1.14\% clade 1). Further, the genetic divergence values observed among the Indian Dunaliella isolates based on ITS sequence variations were considerably higher than that reported in Chlamydomonas spp. (a minimum of $3.5 \%$ between 2 species) by Coleman \& Mai (1997) [39]. Thus, the pattern of genetic divergence, along with the phylogenetic divergence pattern, clearly indicates the presence of at least 5 or more number of species/sub-species among the 10 Indian strains (including $D$. salina and $D$. viridis).

\section{rbcL gene phylogeny}

The pattern of genetic diversity observed among the Indian Dunaliella strains based on $r b c \mathrm{~L}$ gene sequence variations was in accordance with the above observations based on 18S rDNA and ITS analysis except for the positioning of S147 and S135. The phylogenetic tree constructed, using maximum likelihood (Figure 6) analysis with $r b c \mathrm{~L}$ gene sequence data, was forming 2 major clusters with Paulschulzia pseudovolvox as out group. The mean genetic divergence value observed between the 2 clades was $5.89 \%$ and that observed among different isolates of Dunaliella ranged from $0.16 \%$ to $7.73 \%$.

Being a protein coding gene, the pairwise genetic divergence (Tamura 3 parameter) values observed among Dunaliella isolates based on $r b c \mathrm{~L}$ gene sequences were found to be less in comparison with that observed in ITS (a non coding region) sequences. The independent phylogenetic analyses using ITS (Figure 4) and rbcL gene (Figure 6) sequences (Kimura 2 and Tamura 3 parameters respectively) were found to be taxonomically incongruent especially in clade 1 . The major topological change observed was the change in the positioning of the isolate S147. Within $r b c \mathrm{~L}$ phylogeny, this strain from Kutch was found closely allied with clade 1 (Figure 6), whereas, with ITS data it was close to $D$. viridis CONC 002 and other Indian isolates (S125, S133, S115 and S122) in clade 3 (Figure 4). Similarly, the marine D. salina strain S135, got clustered with non-carotenogenic strains in sub-clade $C$ (with divergence of 1.15\%) instead of carotenogenic D. salina (sub-clade B).
Clustering of all the remaining 8 strains in both ITS and $r b c \mathrm{~L}$ phylogenies was more or less similar. As expected S089 (D. salina, CMFRI old strain) clustered with carotenogenic D. salina species CS265 and CCAP $19 / 18$ in clade 1 , (sub-clade $B$, with $100 \%$ similarity). The positioning of 3 strains S086, S118 \& S121 (subclade $C$, in Figure 6) along with $D$. salina/D. viridis UTEX 200/ CCAP 19/3 and D. peircei/D. viridis UTEX 2192 (with $<1 \%$ divergence value) strongly suggests further taxonomic revision. Similarly, in clade 2, the positioning of the Goa isolate S125 (with maximum divergence $7.33 \%$ ) and the clustering of strains S133, S122 \& S115 with D. viridis CONC 002 and D. parva/D. viridis UTEX 1983 (with divergence values 3.15\% \& $0.33 \%$ respectively) was in concordance with ITS phylogeny.

\section{Grouping of Indian Dunaliella strains}

The 2 larger carotenogenic strains $(>20 \mathrm{pg} /$ cell $\beta$ carotene content) S135 and S089 forming the GROUP I, produced $18 \mathrm{~S}$ rDNA size $\sim 2200$ bp and clustered with D. salina CCAP $19 / 18$ and CS265 in ITS phylogeny. These results confirmed the taxonomical identity of the 2 strains as D. salina (Section Dunaliella). But closeness of S135 to the 2 morphologically dissimilar, lower $\beta$-carotene content strains, S121 (Pulicat) and S086 (Tuticorin) in $r b c \mathrm{~L}$ phylogeny has to be noted, which may be due to its marine origin.

GROUP II included the strains S086 (Tuticorin), S118 (Nellore) and S121 (Pulicat), which clustered with D. salina/D.viridis (CCAP 19/3) in ITS phylogeny and had $\sim 2300$ bp band for $18 \mathrm{~S}$ rDNA. The present study shows the closeness of these 3 strains to $D$. salina by molecular analysis (18S rDNA size and ITS \& rbcL phylogenies) rather than by morphological features. These strains were with lesser $\beta$-carotene content $(\sim 2-4 \mathrm{pg} /$ cell $)$ and cells were always green (only S118 turned slightly orange at higher salinity), smaller and with a clear stigma, which were not corresponding with hyper $\beta$-carotene producer strain of $D$. salina and are more or less characters of $D$. viridis [3]. However, there is a description of a greener D. salina (KCTC10654BP) from Korea [17] with low cellular $\beta$-carotene. But 18S rDNA size details are not available for the above Korean strain for comparison. All these factors along with the appearance of $D$. viridis/D. peircei UTEX 2192 close to S118 in $r b c \mathrm{~L}$ phylogeny (clade 1, sub-clade $C$ ) and $18 \mathrm{~S}$ intron phylogeny of $D$. peircei UTEX 2192 by Hajezi et al. [29], emphasizes a need of revisiting the taxonomic identity of all the above reported strains along with the 3 Indian strains using molecular approaches.

GROUP III was formed by 3 strains, S115 (Chennai), S122 (Goa) and S133 (Kutch) allied to D. viridis. This further confirms the possibility of the former 2 strains to be 


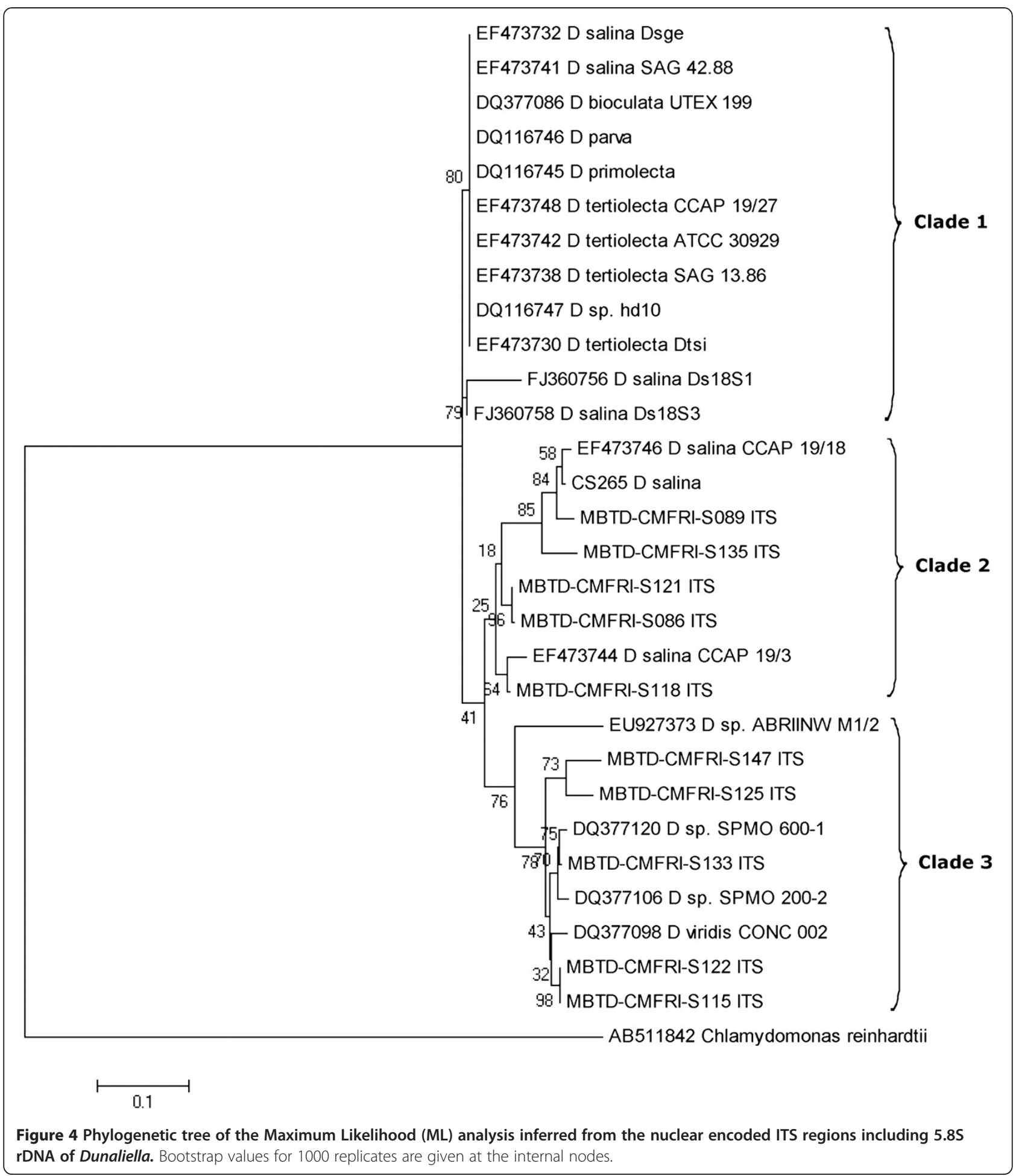

Indian isolates of $D$. viridis, while the presence of 2 stigmata in S133 (only at lower salinity) has to be considered for re-examination and for final taxonomic identification.

The remaining 2 strains S125 and S147 were placed in 2 GROUPs (IV and V) as they were more clearly separated from other Dunaliella strains on the basis of genetic characters than morpho-physiological traits. Based on the taxonomic key [3] the strain S125 was identified as $D$. minuta (longer pyriform cells) but with clear separate starch granules in pyrenoid differing from D. minuta. This strain from Goa salt pan clustered with D. viridis (Figures 4 and 6), but with larger divergence 


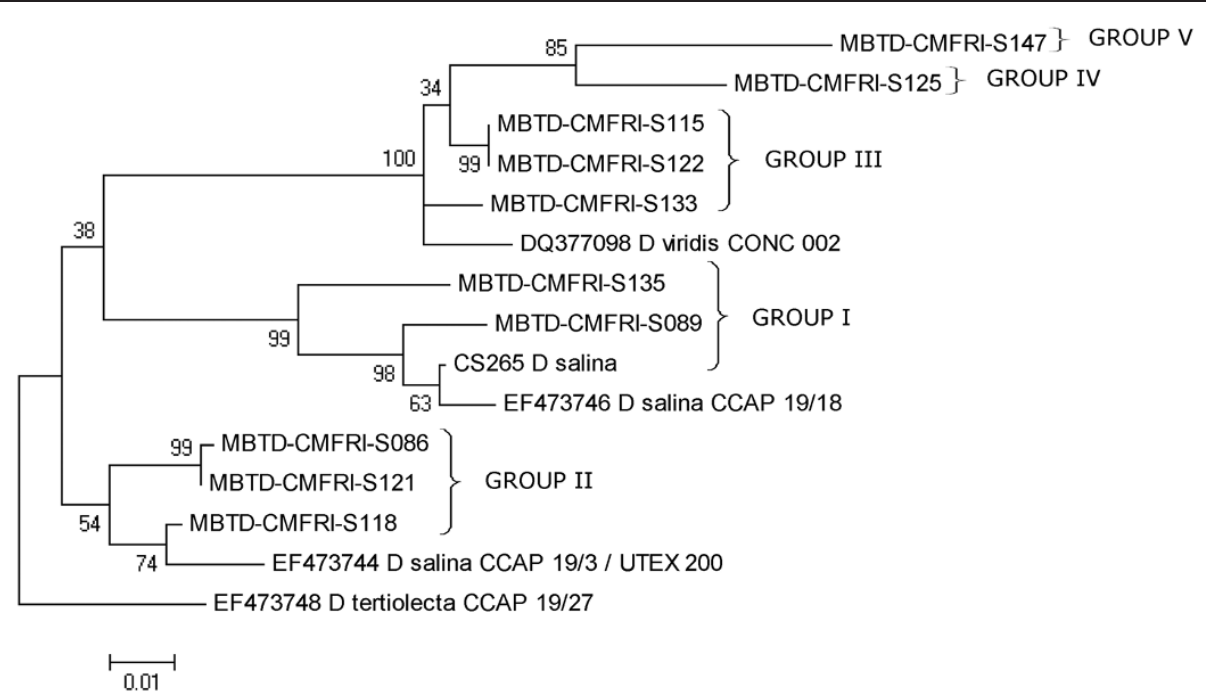

Figure 5 Phylogenetic tree (ML) of ITS region out grouped with D. tertiolecta; illustrated groups of 10 Indian Dunaliella strains. Bootstrap values for 1000 replicates are given at the internal nodes.

values in both (ITS 4.98\%, rbcL 3.84\%) the phylogenies. Further due to the lack of molecular similarity with reported D. minuta (NCBI-BLAST analysis of ITS 2, results not given), the identity of the strain was kept in question and placed in GROUP IV. The identity of the Kutch strain S147 was a little confusing but interesting. It resembled $D$. tertiolecta in general morphology and $18 \mathrm{~S}$ rDNA size ( 1820 bp), while grouped with $D$. viridis in ITS phylogeny (Figures $4 \& 5$ ) and with D. salina in $r b c \mathrm{~L}$ phylogeny (Figure 6). It was isolated from a salt pan, having a dominant palmella stage and with a little higher $\beta$-carotene content (6.7 pg.cell ${ }^{-1}$ ) in stress, while D. tertiolecta was reported as a marine species without a palmella stage in its life cycle [3]. These observations resulted in the grouping of S147 separately as GROUP V and are showing a probability for a new species in the group.

\section{Diversity in Indian Dunaliella strains}

Buchheim et al. [9] have reported diverse community formation of Dunaliella in heteroclimatic hypersaline soils than in purely aquatic habitats. They hypothesized that external factors like temperature and salinity can enhance diversification and apparently got supporting results from the phylogenetic study of about 30 different isolates of Dunaliella (where 3 different morphotypes were characterized), based on 4 genes (18S, 26S, ITS \& $r b c \mathrm{~L})$. Subsequently, Azua-Bustos et al. [40] reported a morphologically distinct, new Dunaliella species, $D$. atacamensis, well adapted for sub-aerial life and with higher genetic divergence from its sister species. Our isolates are purely from aquatic habitats, but with high level of environmental fluctuations, especially in salt pans, and showed high divergence when compared to the reported Dunaliella species (Clade1 of Figures 4 \& 6) from NCBI. The geographic distance and isolation of the locations (Figure 1), from where the strains were obtained could be proposed as a reason for the divergence among the above Indian Dunaliella isolates. However 100\% sequence similarity and morphological resemblance observed between the two isolates S115 and S122 (isolated from Chennai - East coast and Goa - West coast respectively) need to be taken into account.

Grouping pattern observed in the reported Dunaliella strains from NCBI in the cladistic studies ([27,29], present study) suggests a taxonomic revision of the strains especially when there are comments on confusion regarding the taxonomic status of many reported species. Consequently, Browitzka and Siva [3] have proposed an elaborate morphology/physiology based examination of each strain in conjunction with molecular biology. However, among the 28 morphologically differentiated species $[3,8]$, molecular aspects of only few important ones have been extensively studied and reported, and a very large percentage still remains unexplored genetically. Hence, even after a detailed study based on morphology, physiology and molecular aspects, particularly to avoid misnaming, strain codes were assigned to our isolates which are more appropriate for comparative studies as well as for future communications. Morphological and physiological study precisely groups 6 Indian strains into 2 sections - the carotenogenic Section Dunaliella (S089 and S135) and the non-carotenogenic Section Viridis (S115, S122, S133 and S125) [3,7]. The probability of the remaining 4 strains (S086, S118, S121 and S147) to come under Section Dunaliella is much 


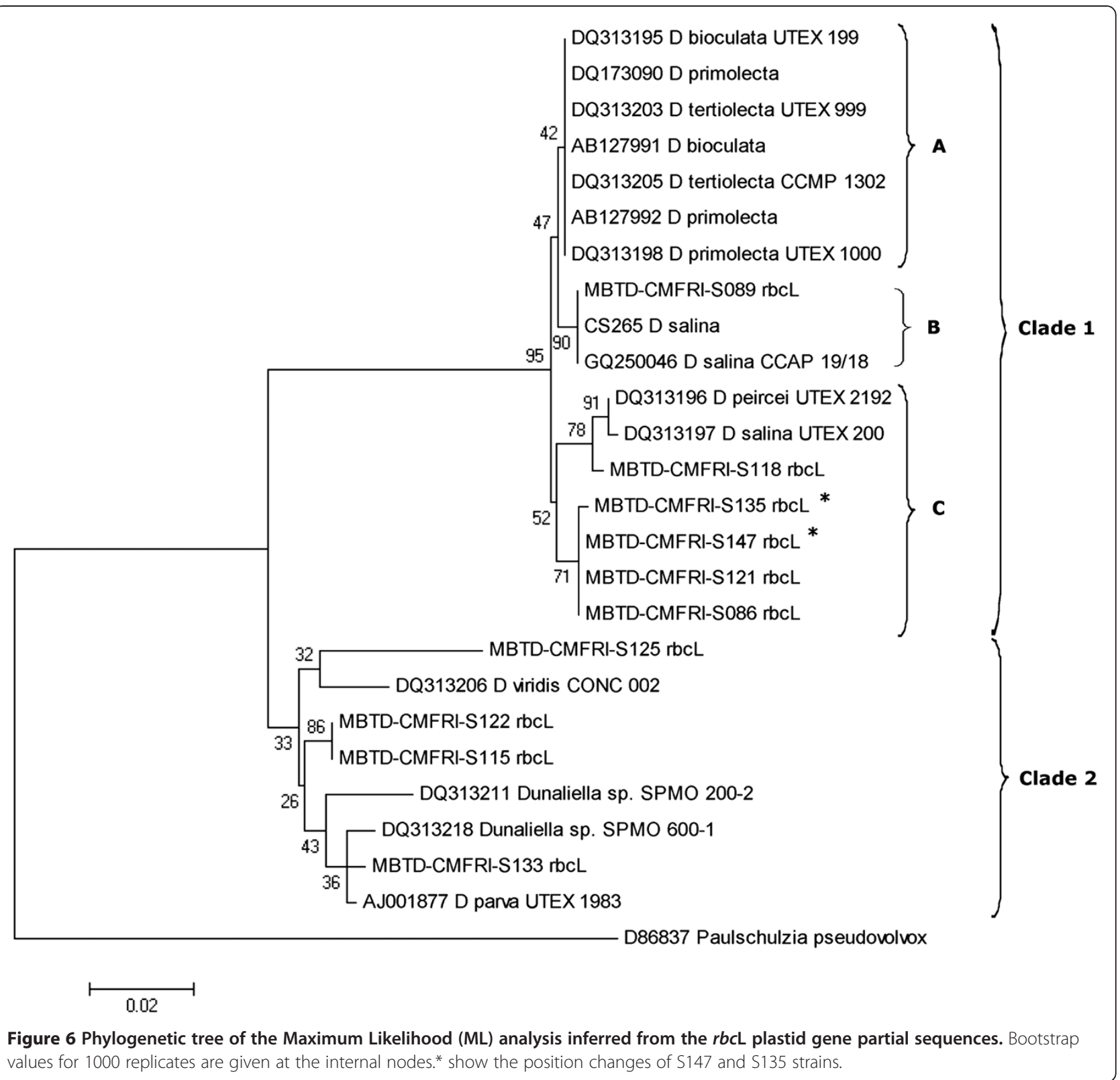

higher as they are more carotenogenic (S147) and closer to D. salina (S086, S118, S121) in molecular analysis. A schematic representation of the diversity in Indian Dunaliella is given in Figure 7.

The sequence diversity within the Indian Dunaliella strains was distinct when compared to the listed species of Dunaliella (ITS region \& $r b c \mathrm{~L}$ gene), and shows possibility of the presence of multiple species in the group. Without the knowledge of sexual compatibility between the genotypes, it is not possible to determine whether this diversity is really representing a biological/evolutionary species or merely an intra-specific diversity (9). However, Coleman et al. [41] have demonstrated a concurrence between ITS sequences and mating ability in
Dunaliella spp. [14]. Since, high level of sequence divergence observed among the Indian Dunaliella strains, could be correlated with sexual incompatibility, chances of more species/subspecies with respect to ITS phylogeny seems to be a realistic possibility. Accordingly, the present study proposes the ITS region to be selected as a molecular marker in taxonomic delineation, which is smaller than 18S rRNA gene (with introns) and more diverged than $r b c \mathrm{~L}$ gene.

\section{Conclusion}

The present study clearly shows high diversity within the Indian Dunaliella and reliability of $18 \mathrm{~S}$ rDNA, ITS region and $r b c \mathrm{~L}$ gene sequencing as a molecular tool in 


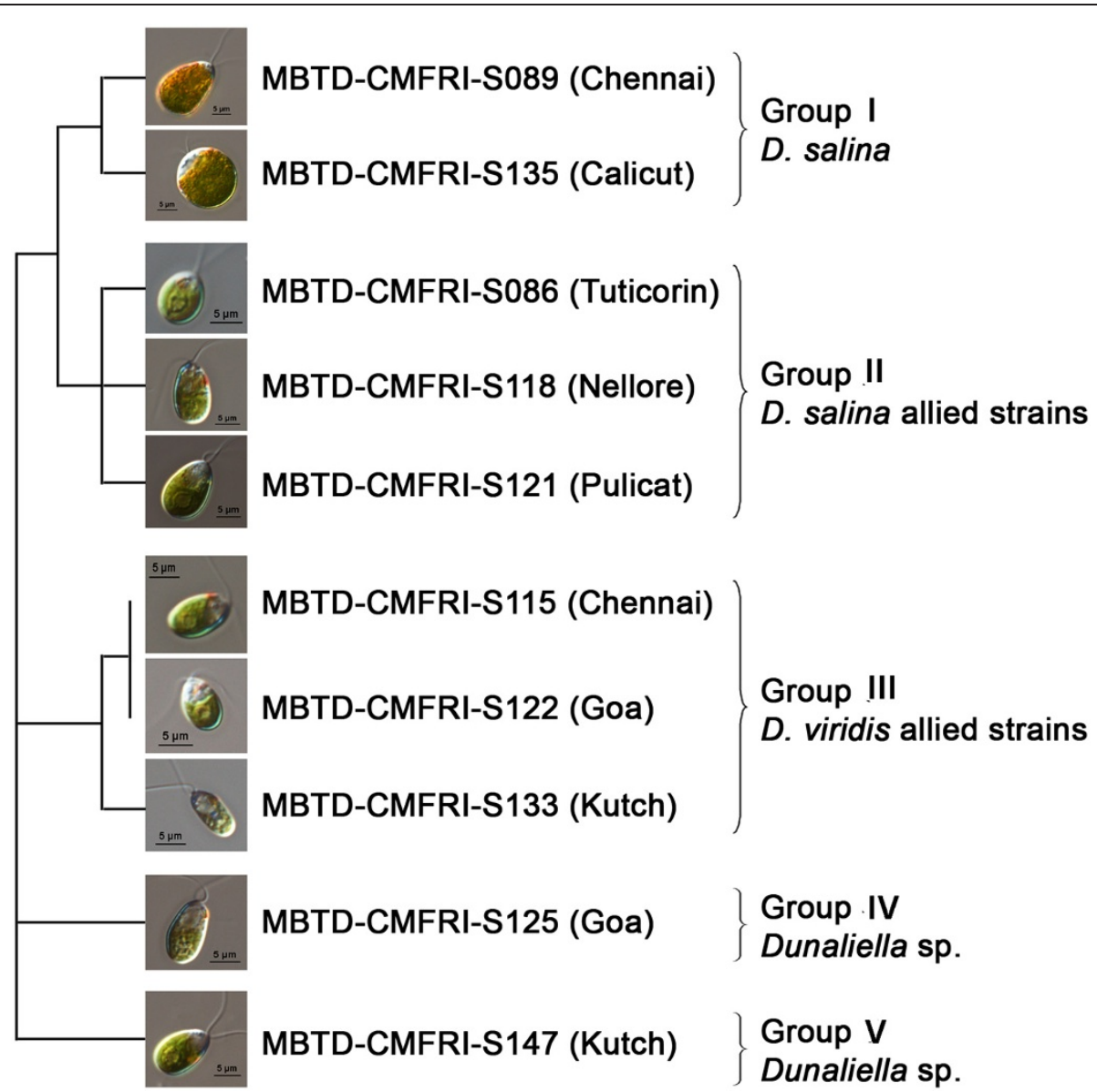

Figure 7 Schematic representation of diversity of Indian Dunaliella. Grouping was done based on the morphology, 18S rDNA size variation (Figure 3) and ITS and rbcL gene phylogenies (Figures 4 \& 5).

species identification and genetic diversity studies. In a recent study, based on morphological parameters Jayapriyan et al. [33] have denoted the presence of 5 species of Dunaliella (D. bioculata, D. tertiolecta, D. viridis, $D$. minuta and D. maritima) from India (east coast). However in the same study, $18 \mathrm{~S}$ rDNA species specific fingerprinting using primers of Olmos et al. [31,38] have illustrated the same isolates as completely different species of Dunaliella (D. parva, D. bardawil and an unidentified Dunaliella sp.). Hence in the present study, for more clarity on the species lineages, along with morphology and 18S rDNA size, phylogenies based on a more diverse ITS region and a more conserved $r b c \mathrm{~L}$ gene were also included, which otherwise are not available for Indian Dunaliella. Consequently, presence of 5 or more species (or sub species), including 2 promising strains of D. salina (Section Dunaliella) and 2 D. viridis? (Section Viridis) strains, has got confirmed. The genetic characterization further helped in the separation of morphologically similar strains and in the clustering of Indian strains of Dunaliella into 5 groups. Similarly, clustering of the reported species in a single clade (Clade
1 with $100 \%$ similarity) in a both the phylogenies clearly emphasizes most careful recording of species names [3]. Hence, for resolving the issue prevailing in Dunaliella taxonomy and for elucidation of taxonomic species lineation of unknown Indian isolates, it is stressed to have further detailed molecular assessment coupled with additional examination of morphological (based on electron microscopy) and biological traits such as reproductive behavior (asexual- palmella, aplanospores etc.) and sexual compatibility.

\section{Materials and methods}

Sampling, isolation and culture conditions

Water samples were collected from selected water bodies along the Indian coast during the months of February to July 2009 (Figure 1 \& Table 1). Strains were isolated by serial dilution directly or after enrichment for a period of 1 or 2 weeks. Further purification was done with agar plating and picking the single colony to obtain unialgal cultures. Dunaliella salina CS265 was purchased from Collection of Living Microalgae, CSIRO, Australia and used as a reference strain. The strain S089 
(D. salina?, an old isolate from Chennai salt pan) was collected from Phytoplankton (aquaculture live feed) Culture Collection at CMFRI, Kochi. After purification, all the cultures were maintained in $75 \mathrm{ml}$ modified Johnson (J/I) medium [10] in $100 \mathrm{ml}$ flasks with $1.5 \mathrm{M}$ ( 200 ppt) $\mathrm{NaCl}$, at temperature $25 \pm 1^{\circ} \mathrm{C}$ and at an irradiance of 40-50 $\mu \mathrm{mol}$ photons $\mathrm{m}^{-2} \mathrm{~s}^{-1}$ supplied by cool white fluorescent lamps on a $12 \mathrm{~h}$ light: $12 \mathrm{~h}$ dark cycle. All cultures were sub-cultured once in a month basis.

\section{Microscopy and morphological study}

Live culture samples were examined using a Nikon 80i Research microscope (Nikon, Japan) with DIC (Differential Interference Contrast) optics and images were captured using Nikon DSFi 1e camera. Major taxonomic features observed include size, shape and colour of the cell, length of flagella, characteristics of stigma, pyrenoid and chloroplast and other cytoplasmic inclusions like refractile granules. Scalar measurements such as cell length and width, were taken from a minimum of 30 cells from each strain randomly during mid growth phase immediately after fixing the cells with 1\% Lugol's iodine. The descriptive statistics such as minimum, maximum, mean and standard deviation were estimated for the above scalar measurements. One way analysis of variance (ANOVA) was performed using SPSS (Version $10.0)$ to identify whether there is any statistically significant difference among different Dunaliella strains for each character.

\section{Salinity tolerance study}

For salinity tolerance study, different Dunaliella strains were cultured in 5 salinity concentrations viz., 0.5, 1.5, 2.5, 3.5 and $4.5 \mathrm{M} \mathrm{NaCl}$ in $150 \mathrm{ml}(250 \mathrm{ml}$ conical flasks) modified Johnson (J/I) medium. Other culture conditions like temperature and light were kept constant as given for normal culture maintenance. Cell characteristics like cell size and colour were examined at late growth phase under DIC microscope (Nikon, Japan). Cell count was taken on every third day using a Neubauer haemocytometer. Cell density was calculated and plotted against days of growth to obtain optimum salinity for each strain.

\section{$\beta$-carotene analysis}

Beta carotene was estimated under normal $(1.5 \mathrm{M} \mathrm{NaCl}$, irradiance of 40-50 $\mu \mathrm{mol}$ photons $\left.\mathrm{m}^{-2} \mathrm{~s}^{-1}\right)$ and stressed (3.5M NaCl, irradiance of 100-150 $\mu \mathrm{mol}$ photons $\mathrm{m}^{-2} \mathrm{~s}^{-1}$ ) growth conditions. Total pigment was extracted from $4 \mathrm{ml}$ culture at late growth phase $\left(25^{\text {th }}\right.$ day) in $4 \mathrm{ml}$ ice cold $100 \%$ acetone. Liquid cultures were centrifuged (8000 rpm, $10 \mathrm{~min}$.), the pellet washed with distilled water and re-suspended in ice cold acetone and left overnight at $-20^{\circ} \mathrm{C}$ until the pellet became colourless.
The extract was centrifuged at $5000 \mathrm{rpm}$ for $5 \mathrm{~min}$ and absorbance was taken for the supernatant at $454 \mathrm{~nm}$ wavelength. Readings were compared with standard curve prepared with synthetic $\beta$-carotene (Type 1, Sigma, USA) in $100 \%$ acetone as described by Hajezi et al. [42]. Cell density was calculated for the same day of extraction and $\beta$-carotene was calculated per cell in picograms.

\section{DNA isolation}

DNA was isolated from $10 \mathrm{ml}$ liquid culture at late growth phase following modified phenol-chloroform method of Wu et al. [43]. Cells were pelletized by centrifugation at $6000 \mathrm{rpm}$ for 5 minutes, washed in distilled water and re-suspended in $450 \mu \mathrm{l}$ TEG ( $25 \mathrm{mM}$ TrisHCl; $10 \mathrm{mM}$ EDTA; $50 \mathrm{mM}$ glucose) buffer ( $\mathrm{pH} 8$ ) with Lysozyme $(5 \mathrm{mg} / \mathrm{ml})$ and vortexed with glass beads and then added $50 \mu \mathrm{l} 10 \%$ SDS. The tubes were then incubated on ice for $10 \mathrm{~min}$. and added $8 \mu \mathrm{l}$ Proteinase $\mathrm{K}(20 \mathrm{mg} / \mathrm{ml})$ and further incubated at $60^{\circ} \mathrm{C}$ for $60 \mathrm{~min}$ in a water bath. Once the cells were lysed completely, the DNA was purified following standard phenol/chloroform extraction and ethanol precipitation [44].

\section{PCR amplification, sequencing and phylogeny}

A gene fragment of $18 \mathrm{~S}$ rRNA was amplified using conserved primers MA1 \& MA2 [5,31]. Reactions were carried out in Veriti Thermal Cycler (Applied Biosystems, US) with a total volume of $25 \mu \mathrm{l}$ containing PCR buffer at $1 \times$ concentration with $1.5 \mathrm{mM} \mathrm{MgCl}_{2}, 0.2 \mathrm{mM}$ each dNTP, $1.5 \mathrm{U}$ of Taq polymerase (Sigma, USA) 5 picomoles of each primer and $25 \mathrm{ng}$ of genomic DNA. Thermal cycling initiated with $3 \mathrm{~min}$ at $95^{\circ} \mathrm{C}$ and then 35 cycles of 30 sec at $95^{\circ} \mathrm{C}, 30 \mathrm{sec}$ at $52^{\circ} \mathrm{C}$ and $2 \mathrm{~min}$ at $72^{\circ} \mathrm{C}$. Final extension was for $10 \mathrm{~min}$ at $72^{\circ} \mathrm{C}$. Amplified products were checked by electrophoresis in $1 \%$ agarose gel. The size (bp) of the amplified product was calculated by comparing it with standard molecular weight DNA marker (Step up 100 bp DNA ladder, Merck, India) using the software Image Lab version 3 (Biorad, USA).

Internal transcribed spacer (ITS) region (700 bp), including ITS1, 5.8 S rRNA and ITS2, was amplified using the primers ITS1 and ITS4 (17). Thermal cycling followed an initial denaturation for $3 \mathrm{~min}$ at $95^{\circ} \mathrm{C}$ and 35 cycles of $30 \mathrm{sec}$ at $95^{\circ} \mathrm{C}, 10 \mathrm{sec}$ at $55^{\circ} \mathrm{C}$ and $45 \mathrm{sec}$ at $72^{\circ} \mathrm{C}$ followed by a final extension at $72^{\circ} \mathrm{C}$ for $7 \mathrm{~min}$. Partial (700 bp) region of $r b c \mathrm{~L}$ gene was amplified using the primers $r b c \mathrm{~L}$ 475-497 and $r b c \mathrm{~L}$ 1181-1160 following Nozaki et al. [45] and Assuncao et al. [46]. The reaction mix composition for ITS and rbcL gene were the same as in the case of $18 \mathrm{~S}$ rRNA gene amplification (given above). Amplified products were tested on $1.5 \%$ agarose gel.

All PCR products were purified using GenElute PCR Cleanup Kit (Sigma, USA) following manufacturer's 
instruction. Cycle sequencing was carried out using forward primers (MA1 and $r b c \mathrm{~L} 475-497$ ) for $18 \mathrm{~S}$ rRNA and $r b c \mathrm{~L}$ genes respectively. Whereas the ITS region was sequenced using both forward (ITS1) and reverse (ITS4) primers. Sequences of DNA fragments were imported to BLAST [47] for similarity searches with available database at NCBI GenBank. The sequence was further aligned with the various available sequences (Table 4) of Dunaliella spp. and, Chlamydomonas reinhardtii (ITS) and Paulschulzia pseudovolvox ( $r b c \mathrm{~L})$ as out groups using the CLUSTAL-W algorithm [48] in Bioedit 7.0 (DNA Sequence Analysis Software package). To clearly illustrate grouping pattern in Indian Dunaliella isolates, D. tertiolecta was out grouped in ITS (Figure 5) phylogeny. Pair wise genetic distances among the different Dunaliella species and between the present isolates were calculated based on Kimura 2 parameter model for ITS region and Tamura 3 parameter for $r b c \mathrm{~L}$ gene. The best nucleotide substitution model selection and phylogenetic analysis based on maximum likelihood (with 1000 boot strap replications) were carried out using MEGA 5 [49]. All the sequence information generated in the present study were deposited in the NCBI database (Table 1).

\section{Competing interests}

The authors declare that they have no competing interests.

\section{Authors' contributions}

KKV and KP conceived the study and wrote the manuscript. KP and CSS did isolation and maintenance of cultures and performed experimental work and data analysis. Molecular data analysis and interpretations were done by $L$. All authors have read and approved the final manuscript.

\section{Acknowledgements}

The authors wish to thank The Director, CMFRI, Cochin, for providing the facilities for undertaking this work. Mariculture Division, CMFRI who provided technical support is duly acknowledged. We thank Dr. P Kaladharan, Principal Scientist and S.I.C, Calicut Research Centre of CMFRI, Calicut and Prof. K J Joseph (Rtd.), School of Marine Sciences, Cochin University of Sciences and Technology (CUSAT), Kochi, for their guidance in morphological identification of the microalgae and Mr. N.K.Sanil, Scientist, MBTD, CMFRI for his help in microscopic studies and for editorial support. The work has been carried out by the financial support provided by National Agricultural Innovation Project (NAIP) and University Grants Commission (UGC).

Received: 4 January 2012 Accepted: 16 October 2012

Published: 1 November 2012

\section{References}

1. Avron M, Ed B-AA: Dunaliella: Physiology, biochemistry and biotechnology. Boca Raton: CRC press; 1992.

2. Ben-Amtoz A: Industrial production of microalgal cell mass and secondary products -Major industrial species Dunaliella. In Handbook of Microalgal Culture. Edited by Amos R. USA: Blackwell Publishing; 2004:273-280.

3. Borowitzka MA, Siva CJ: The taxonomy of the genus Dunaliella (Chlorophyta, Dunaliellales) with emphasis on the marine and halophilic species. J Appl Phycol 2007, 19:567-590.

4. Tafreshi HA, Shariati M: Dunaliella biotechnology: methods and applications. J Appl Microbio 2009, 107:14-35.

5. Olmos SJ, Ochoa L, Paniagua-Michel J, Contreras R: DNA fingerprinting differentiation between $\beta$ - carotene hyperproducer strains of Dunaliella from around the world. Saline Systems 2009, 5:5.
6. Oren A: A hundred years of Dunaliella research: 1905-2005. Saline systems 2005, 1:1-14.

7. Preisig HR: Morphology and taxonomy. In Dunaliella: Physiology, Biochemistry and biotechnology. Edited by Avron M, Ben-Amtoz A. Boca Raton: CRC Press; 1992:1-15.

8. Gonzalez MA, Gomez PI, Polle JEW: Taxonomy and phylogeny of the genus Dunaliella. In The alga Dunaliella, biodiversity, physiology, genomics and biotechnology. Edited by Ben-Amtoz A, Polle JEW, Subba Rao DV. Enfield: Science Publishers; 2009:15-44.

9. Buchheim MA, Kirkwood AE, Buchheim JA, Verghese B, Henly WJ: Hypersaline soil supports a diverse community of Dunaliella (Chlorophyceae). J Phycol 2010, 46:1038-1047.

10. Borowitzka MA, Borowitzka LJ: Dunaliella. In Microalgal Biotechnology. Edited by Borowitzka MA, Borowitzka LJ. New York: Cambridge University press; 1988:27-58

11. Spaulore $P$, Joanni $S$, Cassan C, Duran E, Isambert A: Commercial applications of microalgae. J Biosci Bioeng 2005, 102:87-96.

12. Kleinegris DMM, Janssen $M$, Brandenberg WA, Wijfells RH: The selectivity of milking Dunaliella salina. Mar Biotechnol 2010, 12:14-23.

13. Gomez Pl, Gonzaléz MA: Genetic polymorphism in eight Chilean strains of the carotenogenic microalga Dunaliella salina Teodoresco (Chlorophyta). Biol Res 2001, 34:23-30.

14. Gomez PI, Gonzalez MA: Genetic variation among seven strains of Dunaliella salina (Chlorophyta) with industrial potential, based on RAPD banding patterns and on nuclear ITS rDNA sequences. Aquaculture 2004, 233:149-162.

15. Raja R, Hema IS, Balasubramanyam D, Rengasamy R: Exploitation of Dunaliella for beta-carotene production. Appl Microbiol Biotechnol 2007, 74:517-523.

16. Raja R, Hema IS, Balasubramanyam D, Rengasamy R: PCR-identification of Dunaliella salina (Volvocales, Chlorophyta) and its growth characteristics. Microbiol Res 2007, 162:168-176.

17. Polle JEW, Struwe L, Jin E: Identification and characterization of a new strain of the unicellular green alga Dunaliella salina (Teod.) from Korea. J Microbiol Biotchnol 2008, 18:821-827.

18. Mishra A, Jha B: Isolation and characterization of extracellular polymeric substances from microalga Dunaliella salina under salt stress. Biores Technol 2009, 100:3382-3386.

19. Mishra A, Jha B: Cloning differentially expressed salt induced cDNAs from Dunaliella salina super saturated salt stress using subtractive hybridization. Bot Mar 2011, 54:189-193.

20. Eyden BP: Light and electron microscopic study of Dunaliella primolecta Butcher (Volvocida). J Protozool 1975, 22:336-344

21. Hoshaw RW, Malouf LY: Ultrastructure of the green flagellate Dunaliella tertiolecta (Chlorophyceae, Volvocales) with comparative notes on three other species. Phycologia 1981, 20:199-206.

22. Uriarte I, Farias A, Hawkins AJS, Bayne BL: Cell characteristics and biochemical composition of Dunaliella primolecta Butcher conditioned at different concentrations of dissolved nitrogen. J Appl Phycol 1993, 5:447-453.

23. Gonzalez MA, Coleman AW, Gomez Pl, Montoya R: Phylogenetic relationship among various strains of Dunaliella (chlorophyceae) based on nuclear ITS rDNA sequences. J Phycol 2001, 37:604-611.

24. Teodoresco EC: Organisation et developpement du Dunaliella, nouveau genre de Volvocacee- Polyblepharidee. Beih z Bot Centralb/ 1905, Bd XVIII:215-232.

25. Massyuk NP: Morphology, Taxonomy, Ecology and Geographic distribution of the Genus Dunaliela Teod. and prospectus for its potential utilization. Kiev: Naukova Dumka; 1973 (In Russian).

26. Oliveira L, Bisalputra T, Anita NJ: Ultra structural observation of the surface coat of Dunaliella tertiolecta from staining with cataionic dyes and enzyme treatments. New Phytol 1980, 85:385-392.

27. Gonzalez MA, Gomez PI, Montoya R: Comparison of PCR-RFLP nalysis in the ITS region with morphological criteria of various strains of Dunaliella. J Appl Phycol 1999, 10:573-580.

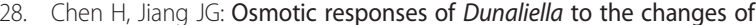
salinity. J Cell Physiol 2009, 219:251-258.

29. Hajezi MA, Barzegari A, Gharajeh NH, Hajezi MS: Introduction of a novel $18 \mathrm{~S}$ rDNAgene arrangement along with distinct ITS region in the saline water microalga Dunaliella. Saline Systems 2010, 6:4

30. Bornet B, Antoine E, Bardouil M, Baut MC: ISSR as new markers for genetic characterization and evaluation of relationships among phytoplankton. J Appl Phycol 2004, 16:285-290. 
31. Olmos SJ, Paniagua MJ, Contreras FR: Molecular identification of Dunaliella sp. utilizing the 18S rDNA gene. Lett Appl Microbiol 2000, 30:80-84.

32. Ramos AA, Polle J, Trau D, Cushman JC, Jin ES, Varela CJ: The unicellular green alga Dunaliella salina as a model for abiotic stress tolerance: genetic advances and future perspectives. Algae 2011, 26:3-20.

33. Jayapriyan KR, Rajkumar R, Sheeja L, Nagaraj S, Divya S, Rengasamy R: Discrimination between the morphological and molecular identification in the genus Dunaliella. Int J Cur Res 2010, 8:73-78.

34. Massyuk NP: New taxa of the genus Dunaliella Teod. I Ukr Bot Zh 1973, 30:175.

35. Ginzburg M, Ginzburg BZ: Ion and glycerol concentrations in 12 siolates of Dunaliella. J Exp Bot 1985, 36:1064-1074.

36. Coesel SN, Baumgartner AC, Teles LM, Ramos AA, Henriques NM, Cancela L, Varela JCS: Nutrient limitation is the main regulatory factor for carotenoid accumulation and for Psy and Pds steady state transcript levels in Dunaliella salina (Chlorophyta) exposed to high light and salt stress. Marine Biotech 2008, 10:602-611.

37. Wilcox LW, Lewis A, Fuerst PA, Floyd GL: Group I introns within the nuclear-encoded small-subunit rRNA gene of three green algae. Mol Biol Evol 1992, 9:1103-1118.

38. Olmos SJ, Paniagua MJ, Contreras FR, Trujillo L: Molecular identification of $\beta$-carotene hyperproducing strains of Dunaliella from saline environments using species specific oligonucleotides. Biotechnol Letters 2002, 24:365-369.

39. Coleman AW, Mai JC: Ribosomal DNA ITS-1 and ITS-2 sequence comparisons as a tool for predicting genetic relatedness. J Mol Evol 1997, 45:168-177

40. Azua-Bustos A, Gonzalez-Silva C, Salas L, Palma RE, Vicuna R: A novel subaerial Dunaliella species growing on cave spider webs on Atacama Desert. Extremophiles 2010, 14:443-452.

41. Coleman AW: The significance of coincidence between evolutionary landmarks found in mating affinity and DNA sequence. Protist 2000 151:1-9.

42. Hajezi MA, Lamarliere C, Rocha JMS, Vermue M, Tramper J, Wijffels RH: Selective extraction of carotenoid from the alga Dunaliella salina with retention of viability. Biotechnol Bioeng 2002, 79:29-36.

43. Wu X, Zarka A, Boussiba S: A simplified protocol for preparing DNA from filamentous Cyanobacteria. Plant Mol Biol 2000, 18:385-392.

44. Sambrook J, Fritsch EF, Maniatis T: Molecular Cloning: a Laboratory Manual. Cold Spring Harbor Laboratory Press: Cold Spring Harbor; 1989.

45. Nozaki H, Ito M, Sano R, Uchida H, Watanabe MM, Takahashi H: Phylogenetic relationships within the colonial Volvocales (Chlorophyta) inferred from rbcL gene sequence data. J Phycol 1995, 31:970-979.

46. Assuncao P, Jaen-Molina R, Caujape-Castells J, Jara A, Carmona L, Freijanes $\mathrm{K}$, Mendoza H: Phylogenetic position of Dunaliella acidophila (Chlorophyceae) based on ITS and rbcL sequences. Dig J Appl Phycol 2011. doi:10.1007/s10811-011-9676-1.

47. Altschul SF, Gish W, Miller W, Myers EW, Lipman DJ: Basic local alignment search tool. J Mol Biol 1990, 215:403-410.

48. Thompson JD, Higgins DG, Gibson TJ: CLUSTAL W: Improving the sensitivity of progressive multiple sequence alignment through sequence weighing, positions specific gap penalties and weight matrix choice. Nucleic Acids Res 1995, 22:4673-4680.

49. Tamura K, Peterson D, Peterson N, Stecher G, Nei M, Kumar S: MEGA5: Molecular evolutionary genetics analysis using maximum likelihood, evolutionary distance, and maximum parsimony methods. Mol Biol Evolution 2011, 28:2731-2739.

doi:10.1186/2046-9063-8-27

Cite this article as: Preetha et al:: Phenotypic and genetic characterization of Dunaliella (Chlorophyta) from Indian salinas and their diversity. Aquatic Biosystems 2012 8:27.

\section{Submit your next manuscript to BioMed Central and take full advantage of:}

- Convenient online submission

- Thorough peer review

- No space constraints or color figure charges

- Immediate publication on acceptance

- Inclusion in PubMed, CAS, Scopus and Google Scholar

- Research which is freely available for redistribution

Submit your manuscript at www.biomedcentral.com/submit
Biomed Central 